\title{
RUSSIAN CAUCASUS DISTRIBUTION OF FOURTEEN HEPATICS RARE AND THREATENED IN EUROPE
}

\author{
NADEZHDA KONSTANTINOVA \& ANATOLIY SAVCHENKo
}

\begin{abstract}
The distribution in the Russian part of the Caucasus of 14 hepatic species rare and threatened in Europe is discussed and mapped based on literature records and specimens collected by the authors. Solenostoma caucasicum (Váña) Konstant. is recorded as new for the Russian part of the Caucasus. New localities for Clevea spathysii (Lindenb.) Müll. Frib., Frullania parvistipula Steph., Frullania bolanderi Austin, Scapania carinthiaca J. B. Jack ex Lindb., S. verrucosa Heeg. and Lophozia ascendens (Warnst.) R. M. Schust. are reported. Their ecology, phytogeography and mode of dispersal in the Caucasus are discussed.
\end{abstract}

Key words: Hepaticae, taxonomy, distribution, phytogeography, reproduction, ecology, Caucasus

Nadezhda Konstantinova \& Anatoliy Savchenko, Polar-Alpine Botanical Garden-Institute, Kola Science Center of the Russian Academy of Sciences, Kirovsk, Murmansk Province, 184256, Russia; e-mail: nadya50@list.ru

\section{INTRODUCTION}

The Caucasus is a mountain system lying between the Black Sea and Caspian Sea. Its flora is highly diverse and specific, owing to the mountains' geographical location between Europe and Asia, their geological history, rich vegetation, and history of flora formation. Unlike the vascular plant flora, the bryophytes there are insufficiently studied. After a comprehensive study of bryophytes by Brotherus (1892), relatively few papers on the hepatics of these mountains were published in the $20^{\text {th }}$ century. Studies of hepatics gathered pace in the $21^{\text {st }}$ century (e.g., Otte 2001, 2006; Konstantinova 2008; Konstantinova et al. 2009b; Konstantinova \& Savchenko 2012; Potemkin \& Doroshina 2009; Potemkin et al. 2010). At present ca 200 species are known for the Russian part of the Caucasus, but knowledge of their distribution and species composition is far from complete. Little is known about the specific ecology and mode of dispersal of hepatics in the Caucasus. A number of species have been reported from a single locality and/or are not supported by recent collections. We have been gathering hepatics in the Caucasus during short field trips since 2005 . In the course of our studies, many species previously known in the Caucasus from only single or a few localities were found not to be rare in these mountains. In this paper we summarize the data on hepatics rare and threatened in Europe which are found in the Caucasus. The known distribution of many species is far from reflecting their real distribution in these mountains but it is useful to have at least a preliminary overview of the ecological characteristics and Caucasian distribution of hepatics threatened in Europe.

\section{MATERIAL AND METHODS}

For this study we compiled all available data on the distribution in the Russian part of the Caucasus (Greater Caucasus) of hepatics rare and threatened in Europe, including literature sources and our unpublished data. The localities of species rare in Europe were mapped in the Caucasus on the basis of coordinates from the labels of specimens we studied or coordinates from literature sources. The label data on voucher specimens of localities new for the Caucasus are cited in full; references are given for published records. Reports of hepatics in the Caucasus are scattered in different publications, sometimes in poorly known issues available only in Russian. We have summarized all these records to make available what is known about the precise distribution and ecology of those species in the Caucasus. Nomenclature 
follows Konstantinova et al. (2009b), with some changes according to Rubasinghe et al. (2011). All specimens examined were collected by Nadezhda Konstantinova and Anatoliy Savchenko, and are stored in the Herbarium of the Polar-Alpine Botanical Garden-Institute of the Kola Science Center of the Russian Academy of Sciences (KPABG).

\section{RESULTS}

\section{ENDEMIC HEPATICS OF THE CAUCASUS}

Although the number of endemic vascular plants for the Caucasus is very high, comprising ca $20 \%$ of the flora (Grossheim 1936), only three hepatic taxa can be considered Caucasian endemics.

Solenostoma caucasicum (Váňa) Konstant. was described from Batumi (Georgia) and recorded from several localities in Georgia and Turkey (Ván̆a 1974). Recently we found this species in the Russian part of the Caucasus, in the Republic of Karachaevo-Cherkessia (Teberda River Basin, Klukhor River valley, on mossy ledges of rock near a rivulet on a steep slope, $43^{\circ} 15^{\prime} 14^{\prime \prime} \mathrm{N}, 41^{\circ} 48^{\prime} 57^{\prime \prime} \mathrm{E}, 1900 \mathrm{~m}$ alt. \# K510-3$05)$. The studied specimen fits $S$. caucasicum but differs slightly in the width of leaves of fertile plants, which are mostly wider than longer. Both the distribution and ecology of $S$. caucasicum are poorly known. The species probably is not rare in the Caucasus. We collected dioicous species of Solenostoma similar to this taxon several times in the Caucasus but are not certain in referring them to $S$. caucasicum. Further studies including analysis of DNA markers will settle it.

Jubula hutchinsiae (Hook.) Dumort. subsp. caucasica Konstant. \& Vilnet. is the next endemic. Based on study of nuclear and chloroplast DNA markers and some morphological characters, Konstantinova and Vilnet (2011) referred all known Caucasian populations of Jubula to Jubula hutchinsiae subsp. caucasica. They also described in detail and mapped the distribution of this taxon in the Russian part of the Caucasus. Here we only emphasize that of all the endemic hepatics in the Caucasus it is most widespread, although usually its populations are relatively small. The species is restricted mainly to the western Caucasus, in areas with relict flora of Colchis where it is not rare on cliffs in deep gorges, especially near waterfalls.

Lophozia wenzelii (Nees) Steph. var. massularioides Bakalin (Fig. 1) was recently described from the Republic of Karachaevo-Cherkessia (Bakalin 2005) and later reported from two localities close to the type locality in the Teberda River valley (Konstantinova 2008) and two localities on the slopes of Yukha Mt. (Konstantinova et al. 2009b). The variety was also collected in the Republic of Adygeya in two localities on Snegovalka Ridge in the Malaya Laba River Basin (Konstantinova et al. 2009b) and two localities in Krasnodar Territory on Aibgo Mt. (Konstantinova \& Savchenko 2011). Lophozia wenzelii var. massularioides is a poorly known taxon with a peculiar appearance partly reflected in its name. According to the original description, the variety differs from the type variety and L. wenzelii var. groenlandica (Nees) Bakalin

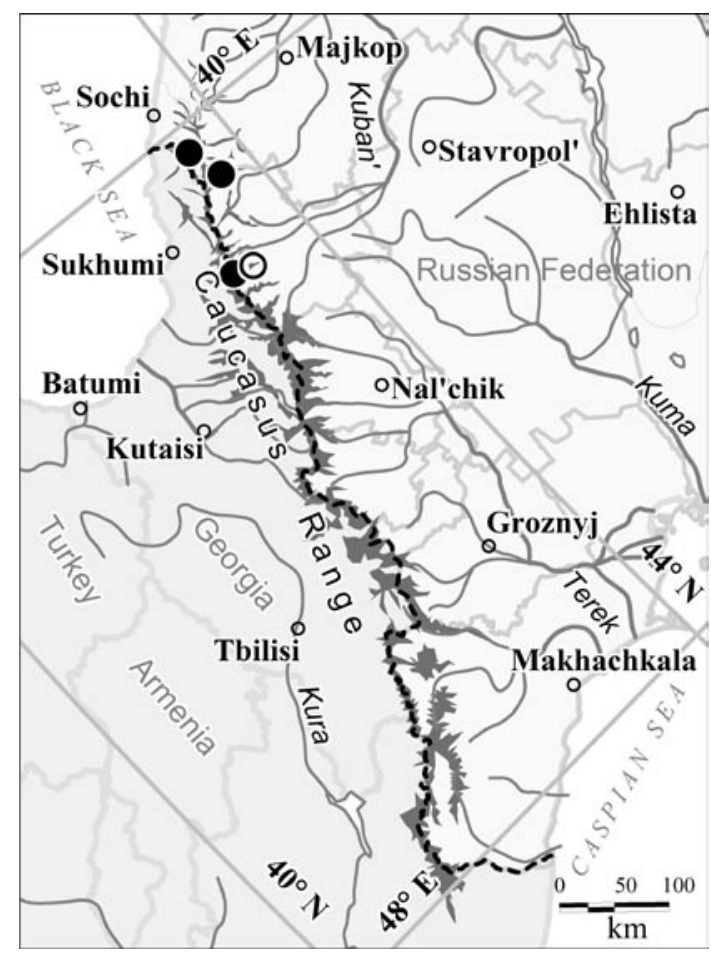

Fig. 1. Distribution of Lophozia wenzelii (Nees) Steph. var. massularioides Bakalin in the Russian part of the Caucasus. locality supported by voucher specimen, $\mathrm{O}$ - literature data. 
in cross section, with undifferentiated cells of the ventral side, and a ventral side more than 5-6 cells wide that does not differ in color from the dorsal side. In our experience, plants of this variety are usually dense-leaved with characteristically capeshaped, relatively symmetrical leaves with a subtransversely inserted dorsal lobe which is either not decurrent or slightly decurrent. In addition, var. massularioides is quite restricted ecologically. It occurs in the subalpine and lower alpine zones at 2000 to $3000 \mathrm{~m}$ a.s.1. in places overgrown with Rhododendron caucasicum Pall. The variety grows on soil among herbs and under Rhododendron in $R$. caucasicum, a herb community, on soil in crevices of cliffs, in thickets of $R$. caucasicum, rarely at the base of hillocks in boggy meadows, sometimes between boulders in rocky streams and on the banks of small streams on subalpine meadows. It usually occurs as pure mats without admixture of other species, or is mixed with Diplophyllum taxifolium, Gymnomitrion concinnatum, Marsupella funckii, Cephalozia ambigua and Pseudolophozia sudetica. Some of our collections do not fit well in this variety even though the habitats and appearance of the plants are quite characteristic. In particular, the color of the ventral side in the upper part of the stem differs slightly from that of the dorsal side, and three or four rows of small cells may be present in the ventral part in cross section. Study of nuclear and chloroplast DNA markers of one such transitional form has revealed that it differs from L. wenzelii var. groenlandica (Vilnet et al. 2008), though very close to it. More detailed morphological and molecular studies are needed to clarify its taxonomical status.

\section{SPECIES ENDANGERED IN EUROPE}

Three species of hepatics designated as endangered in Europe (Schumacker \& Matriny 1995) are recorded from the Russian Caucasus.

Scapania carinthiaca J. B. Jack ex Lindb. (Fig. 2) was first reported for the Caucasus from one locality in the Teberda River Basin (Konstantinova 2008). Later it was found in the Caucasus Strict Nature Reserve in the Molchepa River valley in the Belaya River Basin (Konstantinova

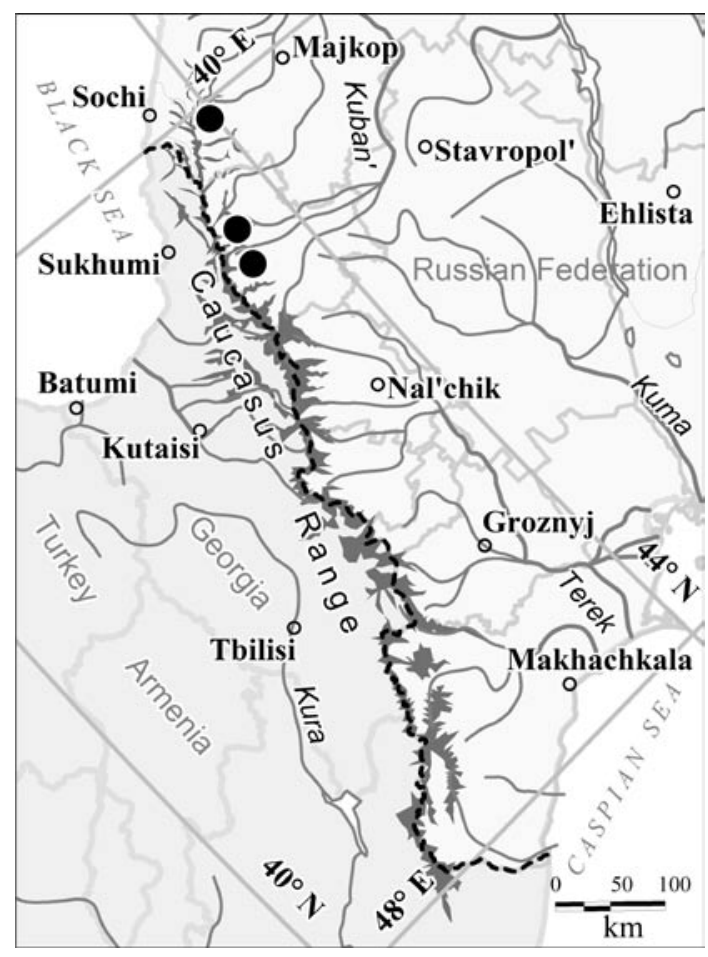

Fig. 2. Distribution of Scapania carinthiaca J. B. Jack ex Lindb. in the Russian part of the Caucasus.

et al. 2009c). In the course of this study we determined this taxon in a specimen collected from the Bolshoy Zelenchuk River valley $\left(43^{\circ} 33^{\prime} 26^{\prime \prime} \mathrm{N}\right.$, $41^{\circ} 18^{\prime} 1^{\prime \prime} \mathrm{E}, 1473 \mathrm{~m}$ a.s.1., spruce-fir forest clearing in a depression with grass-fern thicket and single beech trees, on decaying log of spruce, \# $K$ 01-3a-05). We assigned the specimens to $S$. carinthiaca var. massalongii Müll. Frib. on the basis of the combination of slightly dentate upper leaves and predominantly isodiametric cells of the leaf border. Gemmae are present in all the specimens studied, while the perianth, androecia and sporophytes were found only in a specimen from the Zelenchuk River. Apparently the species is easily disseminated and probably not very rare in the Caucasus. Undoubtedly it is under-recorded because of its small size, frequent occurrence as scattered plants among widespread hepatics (e.g., Blepharostoma trichophyllum), and restriction to montane spruce-fir or spruce forest, which are so far inadequately studied in the Caucasus. 
Scapania carinthiaca is a disjunctive circumboreal species restricted to montane coniferous forests. In Europe it is known from a few localities in Norway, Sweden, Finland, Switzerland, Austria, Germany, the Czech Republic, Slovakia, Poland and Italy, and is red-listed in all those countries (Söderström et al. 2002, 2007). Scapania carinthiaca probably is not rare in the Russian Far East (Choi et al. 2012) and southern Siberia (Konstantinova et al. 2009b; Mamontov et al. 2010; Mamontov \& Afonina 2012) and is rare in North America (Schuster 1974).

Frullania parvistipula Steph. (Fig. 3) was first recorded for the Caucasus from Georgia as F. tenera Lindb. ('Cauc. minor centr.: Carthalinia, Borschom ad lignum putridum', Brotherus 1892). For a long time this species (as F. caucasica Steph.) was known from this locality only. Early in the $21^{\text {st }}$ century the species was recorded as Frullania cf. parvistipula for the Bolschoi Tchatsch (Bolshoy

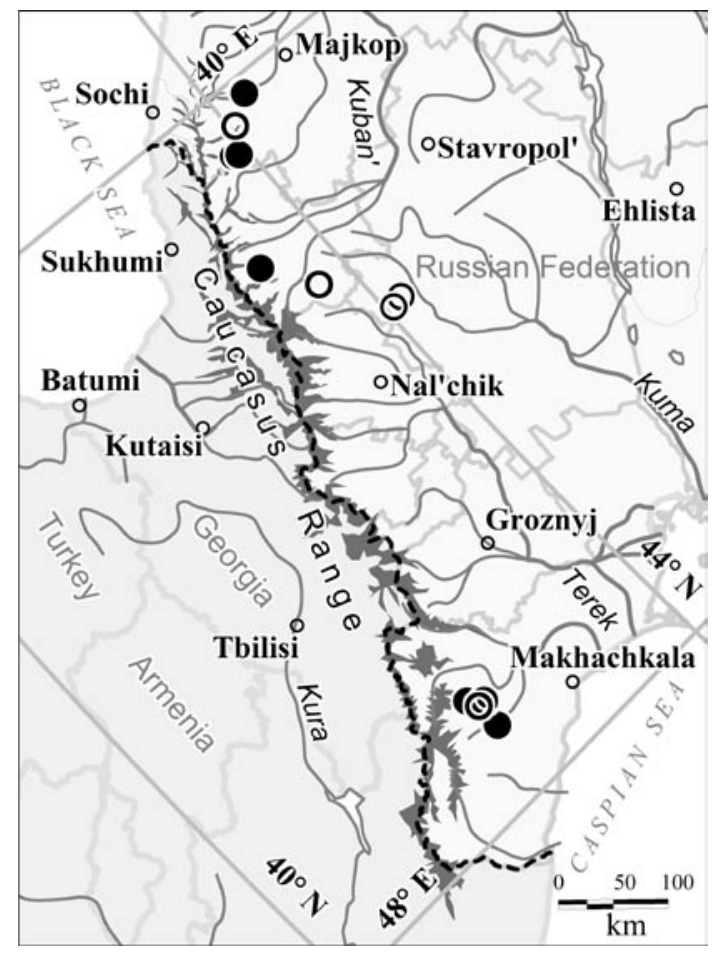

Fig. 3. Distribution of Frullania parvistipula Steph. in the Russian part of the Caucasus. - locality supported by voucher specimen, $\mathrm{O}$ - literature data.
Thach) Nature Park (Otte 2001). Later this identification was confirmed and it was found that the species is far from being rare on the Bolshoy Tkhach Massif (Akatova \& Otte 2007). Many new localities of this species have been found in the last five years, especially in the Eastern Caucasus (Fig. 3) and the Republic of Dagestan (Potemkin et al. 2010; Konstantinova 2011). The known number of collections from other Caucasian republics is low due to insufficient study of hepatics in these republics. Frullania parvistipula was recorded from two localities in the Republic of Karachaevo-Cherkessia (Konstaninova 2008; Potemkin \& Doroshina 2009), one locality in Stavropol Territory (Potemkin \& Doroshina 2009) and several localities in the Republic of Adygeya (Otte 2006; Konstantinova et al. 2009b; Akatova et al. 2010), including our unpublished findings: Malaya Laba River valley, Lower Urushten River, beech forest on steep right bank of the river, $43^{\circ} 55^{\prime} 57^{\prime \prime} \mathrm{N}, 40^{\circ} 40^{\prime} 55^{\prime \prime} \mathrm{E}, 812 \mathrm{~m}$ a.s.l., on decaying wood, \# K101-1-09 and beech forest with ferns, $43^{\circ} 55^{\prime} 53^{\prime \prime} \mathrm{N}, 40^{\circ} 40^{\prime} 28^{\prime \prime} \mathrm{E}, 818 \mathrm{~m}$ a.s.l., on young growth of beech, \# K121-09; dry cliffs on left bank of Urushten River 43 $55^{\prime} 59^{\prime \prime} \mathrm{N}, 40^{\circ} 41^{\prime} 06^{\prime \prime} \mathrm{E}, 804 \mathrm{~m}$ a.s.1., \# K104a-09; left bank of Malaya Laba River, in young beech forest, $43^{\circ} 55^{\prime} 32^{\prime \prime} \mathrm{N}, 40^{\circ} 41^{\prime} 18^{\prime \prime} \mathrm{E}$, $820 \mathrm{~m}$ a.s.l., on young growth of beech, \# K1263-09; Belaya River valley, left bank of Belaya River near village of Khadzhokh, $44^{\circ} 16^{\prime} 52^{\prime \prime} \mathrm{N}$, $40^{\circ} 10^{\prime} 48^{\prime \prime} \mathrm{E}, 382 \mathrm{~m}$ a.s.1., broadleaved forest, on bark of Fagus orientalis Lipsky, \# K492-2-07, on bark of Acer, \# K494-1-07 and on bark of hornbeam, \# K495-1-07; Mishoko River (left tributary of Belaya River), beech-oak forest, right bank of river $44^{\circ} 16^{\prime} 39^{\prime \prime} \mathrm{N}, 40^{\circ} 11^{\prime} 47^{\prime \prime} \mathrm{E}, 511 \mathrm{~m}$ a.s.l., on bark of beech, \# K416-2-10, beech forest on left bank of Mishoko River, $44^{\circ} 16^{\prime} 38^{\prime \prime} \mathrm{N}, 40^{\circ} 11^{\prime} 50^{\prime \prime} \mathrm{E}$, $548 \mathrm{~m}$ a.s.1., on bark of beech, \# K418-2a,b,c-10, mixed with Frullania dilatata and $F$. bolanderi.

The species occurs in broadleaved and mixed coniferous-broadleaved forests from 350 to $2000 \mathrm{~m}$ a.s.1. Potemkin et al. (2010) reported that it was found once in the alpine zone at $2024 \mathrm{~m}$ a.s.1. In the northwestern part of the Caucasus the species occurs mostly on the bark of broadleaved trees (Fagus spp., Fraxinus spp., Carpinus spp., Acer 
spp., Prunus sp.) and occasionally on rocks. In the eastern part of the Caucasus, $F$. parvistipula is restricted mostly to rock outcrops along streams or to crevices in rock, at the shaded bottom of huge rocks, mainly on north-facing slopes, rarely on soil. It often grows in thin mats without admixture of other hepatics. When occurring on tree bark it can be mixed with Frullania dilatata and F. bolanderi. On rocks it sometimes occurs with Lophocolea minor, Porella platyphylla and Radula complanata.

Frullania parvistipula is a predominantly Asiatic species occurring very rarely in Europe and western North America. It is known from Japan, Thailand (Hattori 1978), China (Piippo 1990) and the Asiatic part of Russia where it is rather common in some areas of southern Siberia (Váňa \& Ignatov 1995; our unpublished data), and is recorded from several localities in the south of the Far East (Konstantinova et al. 2009b). In Europe the species is very rare, with the exception of the Caucasus. It has been recorded in a few localities in Switzerland, Austria, Sicily, Italy (Söderström et al. 2002) and Romania (Stefanut 2008), and is red-listed in most countries. The nomenclatural history of Frullania parvistipula is rather complicated. Based on the specimen of Brotherus, Stephani (1910) described F. caucasica Steph., giving $F$. tenera as a synonym. Later S. Hattori (1978) synonymized $F$. caucasica with the Asian F. parvistipula Steph. Schuster (1992) regarded $F$. parvistipula and F. caucasica as subspecies of the North American F. eboracensis Gottsche, but a recent study of nuclear and chloroplast DNA markers (Bombosch et al. 2010) has supported treatment of $F$. parvistipula as a separate species. Sporophytes are not known in Frullania parvistipula, and the species does not produce gemmae, but it easily disseminates via caducous leaves, which probably accounts for its relatively frequent occurrence in some regions of the Caucasus.

Frullania bolanderi Austin (Fig. 4) was first reported for the Caucasus by Otte (2006) from one locality in the Bolshoy Thach ('Bol'šoj Tchač') Mts (Krasnodar Territory) and one locality in the Republic of Adygeya. Konstantinova et al. (2009c) then recorded two localities in the Caucasus Strict

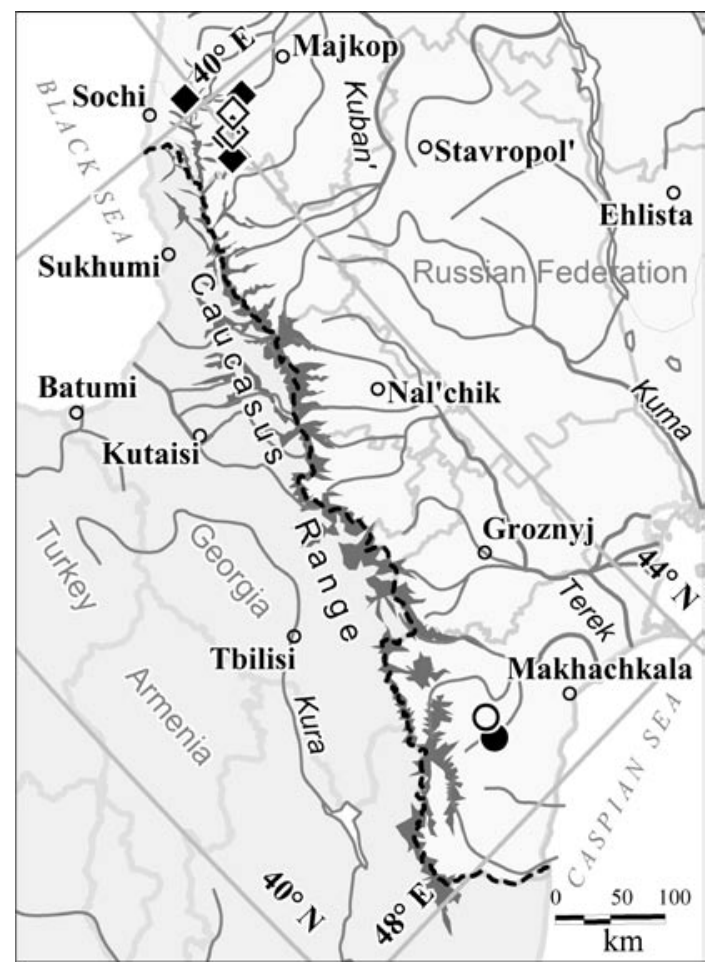

Fig. 4. Distribution of Frullania bolanderi Austin $(\diamond \diamond)$ and Frullania inflata Gottsche ( $\mathrm{O}$ ) in the Russian part of the Caucasus (black signature - locality supported by voucher specimen, empty signature - literature data).

Nature Reserve, and Akatova et al. (2010) gave one locality in the Belaya River valley. We identified more specimens of it in the course of recent examination of our previous collections from the Republic of Adygeya, as follows: Mishoko River (left tributary of Belaya River), beech-oak forest on right bank of river $44^{\circ} 16^{\prime} 39^{\prime \prime} \mathrm{N}, 40^{\circ} 11^{\prime} 47^{\prime \prime} \mathrm{E}, 511 \mathrm{~m}$ a.s.l., on beech bark, \# K416-2-10, and in beech forest on left bank of Mishoko River, $44^{\circ} 16^{\prime} 38^{\prime \prime} \mathrm{N}$, $40^{\circ} 11^{\prime} 50^{\prime \prime} \mathrm{E}, 548 \mathrm{~m}$ a.s.l., on beech bark, \# K4182a,b,c-10, mixed with Frullania dilatata and F. bolanderi; Malaya Laba River Basin: right bank of Urushten River, fern-beech-hornbeam forest, $43^{\circ} 55^{\prime} 53^{\prime \prime} \mathrm{N}, 40^{\circ} 40^{\prime} 28^{\prime \prime} \mathrm{E}, 818 \mathrm{~m}$ a.s.l., on bark of Fagus orientalis (ca $0.2 \mathrm{~m}$ diameter), at ca $2 \mathrm{~m}$ height, mixed with Frullania dilatata, \# K119a-

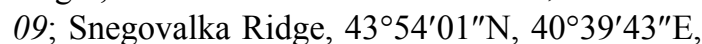
$1751 \mathrm{~m}$ a.s.l., fir-beech forest, on Sorbus mixed with Frullania dilatata, \# K162-3a-09, and in 
beech grass-fern forest, on beech, \# K163-1a, $2 a$ 09 , and in beech-maple forest, on bark of maple, \# K164-09.

The species occurs on bark of Fagus, Carpinus, Sorbus and Acer, and was collected on rock once. It is restricted mostly to mixed forests at 540 $1800 \mathrm{~m}$ a.s.1.

Frullania bolanderi is a disjunctive circumboreal species. Its range in North America 'is in part relict distribution' (Schuster 1992). In Europe Frullania bolanderi is known from Norway, Sweden (Söderström et al. 2002), and European Russia where the species was recently recorded from many provinces (Konstantinova et al. 2009b) and probably is not very rare (Fig. 5). The species is not rare in the Far East of Russia (1.c.) and to our knowledge it is one of the commonest in some regions of southern Siberia, the Khamar Daban range in particular. It has never been collected with sporophytes but is easily disseminated by means of caducous leaf lobes. The species is easily recognizable due to the presence of characteristic leafless branches and no doubt will be found in many localities in future studies of Caucasian hepatics.

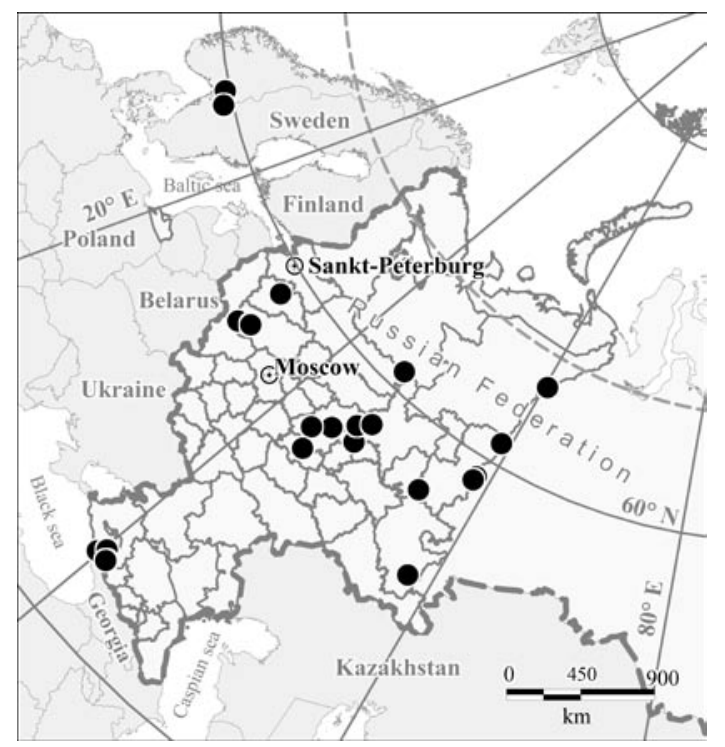

Fig. 5. Distribution of Frullania bolanderi Austin in Europe.

\section{HEPATICS VULNERABLE IN EUROPE}

Three hepatics regarded as vulnerable in Europe (Schumacker \& Matriny 1995) occur in the Russian part of the Caucasus. Jubula hutchinsiae subsp. javanica was discussed above under J. hutchinsiae subsp. caucasica. Pallavicinia lyellii (Hook.) Carruth. has been reported from only one locality in the Russian part of the Caucasus: the Khosta River valley (Konstantinova et al. 2009b). The third species, Frullania inflata Gottsche (Fig. 4), was first recorded from one locality in the Republic of Dagestan on the Gunib Plateau (Potemkin et al. 2010). Later Konstantinova (2011) collected it there as well, and also found it in hornbeam wood near the town of Tsudakhar (Inner Mountainous Dagestan) where it is rather common. This hepatic is a predominantly Asiatic-North American species and probably is not rare in Siberia and the Far East (e.g., Konstantinova et al. 2009b; Bakalin 2010; Mamontov et al. 2011). In Europe F. inflata is known from Albania, Austria, Switzerland, Hungary, the Czech Republic, Italy and Sicily (Söderström et al. 2002, 2007).

\section{HEPATICS RARE IN EUROPE}

Of the 70 hepatics designated 'rare' in the Red Data Book of European Bryophytes (Schumacker \& Matriny 1995), six occur in the Russian Caucasus. Two of them are known from single localities so far.

Isopaches decolorans (Limpr.) H. Buch is recorded from two localities in the Teberda River Basin, on Malaya Khatipara Mt. at $2750 \mathrm{~m}$ a.s.l. and on Mussa-Achitara Mt. at 2985 m a.s.l. (Konstantinova 2008). It is a rare arctic montane species with a disjunctive worldwide distribution.

Lophoziopsis propagulifera (Gottsche) Konstant. \& Vilnet (Lophozia latifolia R. M. Schust.) is known from one locality on Yukha Ridge in the Republic of Karachaevo-Cherkessia (Konstantinova et al. 2009b). This bipolar species is not rare, occurring both in tundra and forest-tundra biomes and in the alpine and subalpine zones of northern mountains (Bakalin 2005). It is quite possible that new localities of both above-mentioned species 
will be found in future studies of barely accessible subalpine and alpine zones of the Greater Caucasus. The known distribution of the other four species rare in Europe and occurring in the Caucasus has been expanded recently and is discussed in more detail.

Clevea spathysii (Lindenb.) Müll. Frib. [Athalamia spathysii (Lindenb.) S. Hatt.] (Fig. 6) was recorded for the Caucasus by Schumcker and Váňa (2005) but we could not find any reports supporting this reference. Recently it was found on the Gunib Plateau (Inner Mountainous Dagestan) where it was collected in six localities (Potemkin et al. 2010; Potemkin \& Urbanavichus 2010; Konstantinova 2011). Apart from the Republic of Dagestan, we collected it in the Malaya Laba River valley in deep rocky crevices, in shrub thickets on dry southeast-facing cliffs on the left bank of the Urushten River, $43^{\circ} 55^{\prime} 59^{\prime \prime} \mathrm{N}, 40^{\circ} 41^{\prime} 6^{\prime \prime} \mathrm{E}$, 804 m a.s.1., \#\# K105-1-09, K115-2,4-09. In the Caucasus the species occurs on soil or limestone in crevices and small caves in calcareous rock at 800-2300 m a.s.1.

Clevea spathysii is a predominantly Mediterranean species occurring in some parts of North Africa, the Canary Islands, Mediterranean countries as well as in South and East Africa, on the Arabian Peninsula (Oman, Yemen), Jordan (Perold 1999), and in western North and South America (Rubasinghe 2011). In most European countries it is rare (Söderström et al. 2002).

Scapania verrucosa Heeg. was known in the Caucasus for a long time from several localities in Georgia (Abramov et al. 1963, 1964, 1966) and the Republic of Dagestan (Abramov \& Abachev 1968), and in the last five years it has been found in many areas we studied (Fig. 7). In the western and northwestern Caucasus it does not seem to be rare. In particular, in Krasnodar Territory the species is sometimes abundant in valleys of Shakhe River tributaries (Konstantinova et al. 2009b) and was collected in several localities in the valleys of the Psezuapse and Ashe Rivers (Konstantinova \& Savchenko 2012). In the Republic of Adygeya the species is quite common in the valley of the Belaya River and its right tributary, the Molchepa River, near the town of Guseripl',

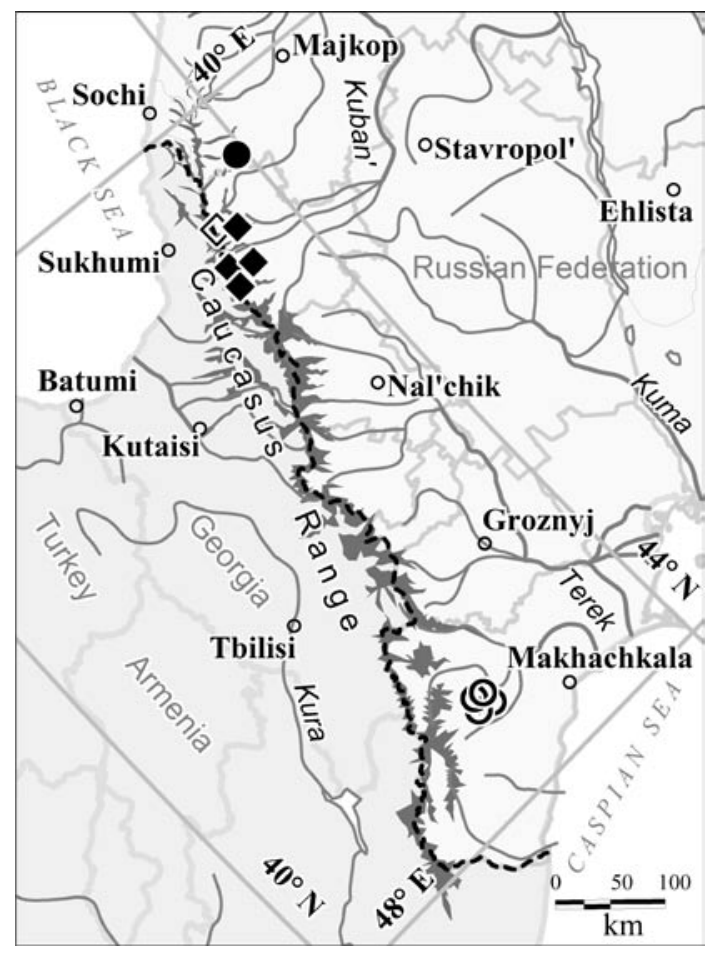

Fig. 6. Distribution of Clevea spathysii (Lindenb.) Müll. Frib. $(\bullet$ ) and Lophozia ascendens (Warnst.) R. M. Schust. $(\diamond \diamond)$ in the Russian part of the Caucasus (black signature - locality supported by voucher specimen, empty signature - literature data).

occurring as well in the Malaya Laba River Basin (Konstantinova et al. 2009b). In the Republic of Karachaevo-Cherkessia it occurs in the Teberda River Basin, where it was found in several localities and is abundant on cliffs along the lower Azgek River (Konstantinova 2008), at one locality in Daut Ravine (Potemkin \& Doroshina 2009), and in the Bol'shoy Zelenchuk River Basin on the left bank of Rybnyi Stream on mosses and rocks on cliffs near waterfall, $43^{\circ} 33^{\prime} 45^{\prime \prime} \mathrm{N}, 41^{\circ} 21^{\prime} 3^{\prime \prime} \mathrm{E}$, 1427 m. a.s.1., \#\# K609-5, -9, -11-05. The species was also found in one locality in the Republic of Kabardino-Balkariya (Konstantinova et al. 2009b) and several localities in the Republic of Dagestan (Abramov \& Abachev 1968; Konstantinova 2011). In the western and northwestern Caucasus it apparently is not rare and sometimes even abundant, especially near waterfalls. 
Scapania verrucosa occurs at $140 \mathrm{~m}$ a.s.1. (Aul Tkhagapsh, Psezuapse River Valley) up to $2090 \mathrm{~m}$ a.s.l. (Republic of Dagestan, Gunukh Ravine). It usually grows in deep gorges, mostly on moist soil and fine earth covered with neutral rock, sandstone, rare on decaying wood in stream beds, on sandy or peaty soil in crevices of wet cliffs, and among mosses on mossy cliffs near the edge of streams and waterfalls. The species always has gemmae, which often are abundant, but no perianth or androecia have been found in the Caucasus. Sporophytes are unknown in this species (Gradstein \& Váňa 1987).

Scapania verrucosa is a highly disjunctive but mostly European species. In Europe it is known in France, Austria, Switzerland, Italy, Spain, Bosnia and Herzegovina, Croatia, Slovenia, Romania, Bulgaria and Ukraine (Söderström et al. 2002, 2007). In most of these countries it is rare or very rare. Outside of Europe it is recorded from the

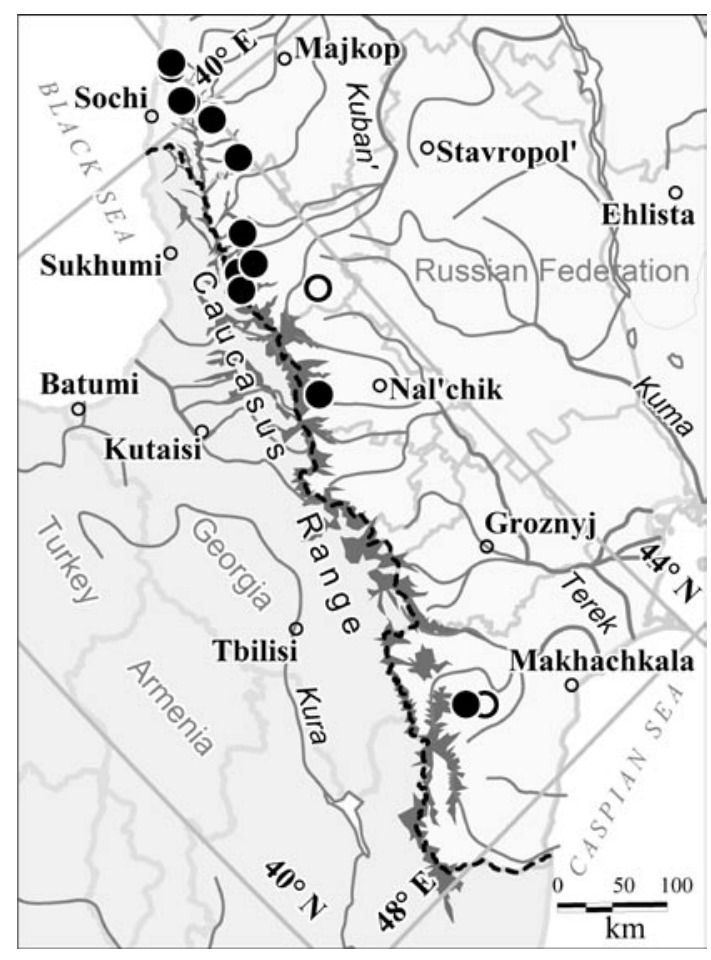

Fig. 7. Distribution of Scapania verrucosa Heeg in the Russian part of the Caucasus. - locality supported by voucher specimen, $\mathrm{O}$ - literature data.
Himalayas, China, and one locality in Mexico (Gradstein \& Váňa 1987), and with a question mark from the Russian Far East (Konstantinova et al. 2009b).

Liochlaena subulata (A. Evans) Schljakov (Fig. 8) was first recorded from the Caucasus by Ván̆a (1973) based on specimens collected by Abramova and Abramov in Georgia (Borzhomi, Batumi). Probably the first report of this species from the Russian part of the Caucasus was from Duda (1982, one locality in the Matsesta River valley). In the last five years we have found that it is not rare at lower elevations in the western and northwestern parts of the Caucasus (Fig. 8). In the Republic of Adygeya it was collected at different sites of the Belaya River valley and its right tributary, the Molchepa River, near the town of Guseripl', and also in the Malaya Laba River Basin (Konstantinova et al. 2009b). More commonly it grows on mountains facing the Black Sea in Krasnodar Territory; in particular, it is frequently observed and sometimes is abundant in valleys of Shakhe River tributaries (Konstantinova et al. 2009b) and in the Mzymta, Eastern Dagomys, Psezuapse, and Kuapse River valleys (Konstantinova \& Savchenko 2011, 2012). The species is also reported from a single locality in Stavropol Territory (Potemkin \& Doroshina 2009) and in Kabardino-Balkaria, in the Cherek-Bezengiysky River valley (Konstantinova et al. 2009a).

Liochlaena subulata occurs more often in deep canyons on stream banks in the zone of broadleaved and mixed forest, including forests with Rhododendron ponticum and R. caucasicum in the understory from $80 \mathrm{~m}$ a.s.l. (near the Black Sea coast) up to $850 \mathrm{~m}$ a.s.l. in Kabardino-Balkaria (central Caucasus). The species grows both on decaying wood and bark of broadleaved trees at their bases irrigated by running water and shaded cliffs (mostly sandstone) hidden in thickets of shrubs and grasses. The second species of the genus, Liochlaena lanceolata, is restricted in the Caucasus to higher elevations, mostly on decaying wood in mixed or coniferous forests.

The species is freely disseminated in the Caucasus both by the gemmae always present on elongated shoots with modified leaves, and spores. 
Although dioicous, L. subulata often occurs with a perianth and androecia and several times was collected with sporophytes ripening in October or November.

Liochlaena subulata is mainly a Eurasian species with a disjunctive distribution in the Hawaiian Islands and western North America. In Europe it occurs rarely in Sweden, France, Poland, Germany, Austria, Hungary, Switzerland, the Czech Republic, Slovenia, Romania, Estonia, Lithuania and Ukraine (Söderström et al. 2002, 2007). The species was recorded in several provinces of the European part of Russia (Leningrad, Novgorod, Nizhniy Novgorod and Perm Provinces) where it is known from single localities (Konstantinova et al. 2009b).

Lophozia ascendens (Warnst.) R. M. Schust. (Fig. 6) was first reported for the Russian part of the Caucasus by Váňa (1982) from one locality in the Teberda River valley (Amanaus Ravine). We collected this species several times in coniferous forests in valleys of Teberda tributaries: the Mukha, Alibek and Klukhor (Konstantinova 2008). Recently we determined this taxon in specimens collected in the Bolshoy Zelenchuk River valley $\left(43^{\circ} 33^{\prime} 26^{\prime \prime} \mathrm{N}, 41^{\circ} 18^{\prime} 1^{\prime \prime} \mathrm{E}, 1473 \mathrm{~m}\right.$ a.s.l., in sprucefir forest, clearing in a depression with grass-fern thicket and single beech trees, on decaying log of spruce, \# K601-3b-05). The species was also recorded on Sophiya Mt. in Arkhys (Potemkin \& Doroshina 2009).

Lophozia ascendens is a circumboreal species reported from many European countries but generally regarded as rare (Söderström et al. 2002). In Russia's European region it was recently found in many provinces (Konstantinova et al. 2009b), in most of which it is rare.

In the Caucasus, L. ascendens often occurs as a few stems mixed with other hepatics characteristic of decaying wood, particularly with Anastrophyllum michauxii (F. Weber) H. Buch, Calypogeia suecica (Arnell \& J. Perss.) Müll. Frib., Scapania apiculata Spruce, S. carinthiaca, Lepidozia reptans (L.) Dumort., Blepharostoma trichophyllum (L.) Dumort. and Riccardia palmata (Hedw.) Carruth. It always has gemmae; many of the examined specimens contained perianths.

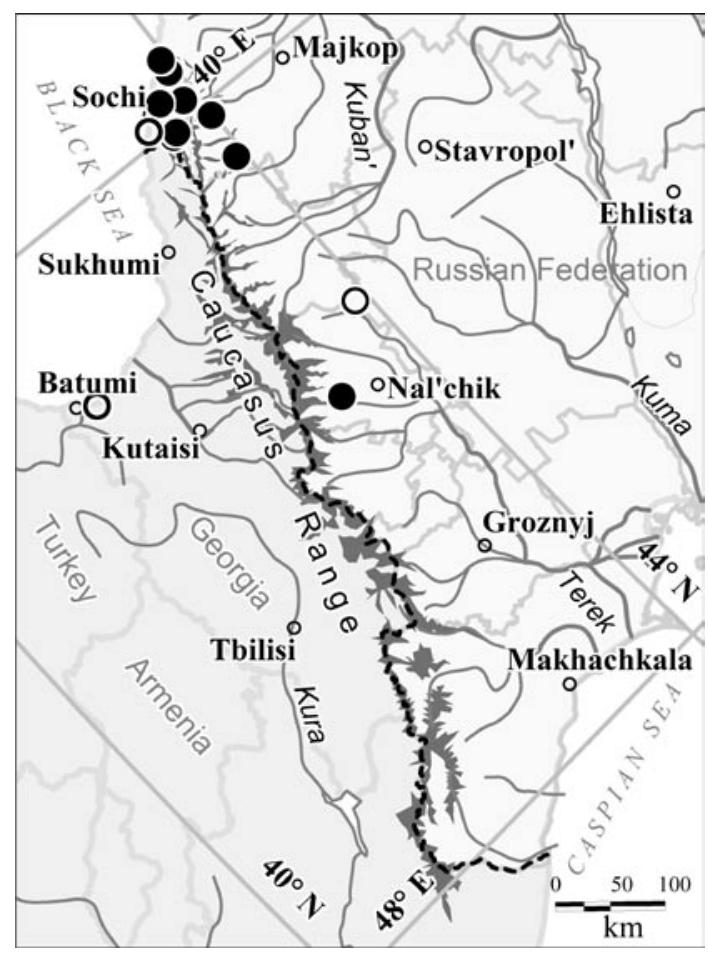

Fig. 8. Distribution of Liochlaena subulata (A. Evans) Schljakov in the Russian part of the Caucasus. - locality supported by voucher specimen, $\mathrm{O}$ - literature data.

L. ascendens apparently is not rare in the Caucasus and is under-recorded due to poor knowledge of the hepatics of coniferous forests in the Caucasus, the small size of the plants, and their usually sparse occurrence.

\section{DISCUSSION}

Three hepatics endemic to the Caucasus and 11 hepatics rare and threatened in Europe occur in the Russian part of the Caucasus. Some of them are known here from one (Lophoziopsis propagulifera, Solenostoma caucasicum, Pallavicinia lyellii) or a few (Isopaches decolorans, Scapania carinthiaca) localities. Several are not rare at least locally (Clevea spathysii, Frullania bolanderi, F. inflata, Lophozia ascendens, L. wenzelii var. massularioides, Jubula hutchinsiae subsp. caucasica) or even widespread and abundant (Frullania parvistipula, Liochlaena subulata, Scapania verrucosa). 
As clearly seen from the maps, many localities of the above-mentioned species are concentrated mostly in the northwestern part and less frequently in the southeastern part of the mountains. This can be explained mainly by much better study of hepatics in the northwestern part of the Caucasus than in the southeastern or central parts of the mountains. Based on this assumption and our experience collecting hepatics in the Caucasus, we suggest that most of these examined hepatics have a trans-Caucasian distribution. This is most evident for Scapania verrucosa (Fig. 7) and Frullania parvistipula (Fig. 3), which were collected in most of the areas studied. So far, circumboreal Scapania carinthiaca and Lophozia ascendens are known from very few localities, but this must be due to insufficient study of the coniferous forests of the Caucasus. We focused our studies on subalpine and alpine zones and the lower broadleaved forest zone, ignoring for the time being the coniferous and mixed forests. The same is true for Frullania bolanderi, currently known solely from the northwestern Caucasus. One of the discussed hepatics, Clevea spathysii, is an obligate calciphilous species restricted to specific habitats which remain practically unexplored, such as the huge limestone areas of the Scalisty and Pastbishchny ranges. Future exploration of the limestone rock areas of the Caucasus should reveal numerous localities of this species. We also expect that the Caucasian distribution of arctic montane Isopaches decolorans and Lophoziopsis propagulifera will be expanded in the course of study of barely accessible alpine zone of the Caucasus. Very few areas in the alpine zone of the Russian Caucasus have been studied. One endemic hepatic in the Caucasus, Lophozia wenzelii var. massularioides, also seems to have a trans-Caucasian distribution. It usually occurs in the subalpine and alpine zones under Rhododendron caucasicum thickets, which are characteristic for the Greater Caucasus.

Several of the species under discussion have quite restricted ranges. Jubula hutchinsiae subsp. caucasica occurs (Konstantinova \& Vilnet 2011) exclusively in the area belonging to the Euxine floristic province sensu Takhtajan (1978). In the
Russian Caucasus it is restricted to the lower mountain slopes facing the Black Sea coast between the Abkhazian border (Mzymta River Basin) and the city of Tuapse. This is a well-known refuge of Arctic-Tertiary flora (flora of Colchic). Several enclaves of impoverished Colchic flora have also persisted southeast of the Black Sea coast in the valleys of the Belaya and Laba Rivers (Pavlov 1948), where Jubula hutchinsiae subsp. caucasica also is not rare in deep shaded ravines in the Belaya River valley.

Most of the discussed hepatics have a relict, highly disjunctive distribution or else are endemic to the Caucasus. Several territories in the western and southeastern parts of the mountains were never glaciated and then were isolated for a prolonged period. The Tertiary flora has been preserved in these areas, and many Caucasian endemics have evolved during their long isolation (Grossheim 1936; Pavlov 1948). Here we shall not speculate about the age of hepatic relicts in the Caucasus, as this requires careful phylogeographic analyses. It is reasonable, however, to suggest that at least the temperate mesophytic Frullania bolanderi, F. parvistipula, Liochlaena subulata and Scapania verrucosa, with their highly disjunctive ranges restricted mainly to nonglaciated areas, are remnants of Arctic-Tertiary flora of the Turgay (Angarida) type, whereas the mostly subtropical Jubula hutchinsiae subsp. caucasica, Pallavicinia lyellii and probably Clevea spathysii can be referred to the subtropical flora of the Poltava type. All these species seem to have survived the Pleistocene glaciation in the lower zones of the western part of the mountains, later spreading more or less successfully throughout the entire Caucasus. As recently discovered (Konstantinova \& Vilnet 2011), some of these species have evolved to become endemic subspecies (Jubula hutchinsiae subsp. caucasica). On the other hand, we consider several of the arctic-montane species (Isopaches decolorans, Lophoziopsis propagulifera, Lophozia wenzelii var. massularioides) to be glacial relicts. These species are likely to be remnants of the time of mountain glaciation of the Caucasus. 
ACKNOWLEDGMENTS. We are grateful to the anonymous reviewer for helpful comments. This work was supported by the Russian Foundation for Basic Research (grants 09-04-10078, 11-04-10135, 12-04-01476).

\section{REFERENCES}

Abramov I. I. \& ABACheV A. Yu. 1968. On bryophytes of Dagestan. Novosti Sist. Nizsh. Rast. (1968): 311-322 (in Russian).

Abramov A. L., Abramov I. I. \& Duda J. 1964. Ad floram caucasicam Heparicarum (Reservatum publicum Teberdense). Novosti Sist. Nizsh. Rast. (1964): 280-285 (in Russian).

Abramov I. I., ABRAmovA A. L. \& DudA J. 1963. Ad floram Caucasicam Muscorum Heparicarum Reservatum Publicum Lagodecii. Notula systematicae e sectione cryptogamica Instituti Botanici Academiae Scientarum URSS 16: 168-172 (in Russian).

ABramov I. I., ABRAmovA A. L. \& DudA J. 1966. Ad floram caucasicam Heparicarum (Adzharia). Novosti Sist. Nizsh. Rast. (1966): 287-297 (in Russian).

Akatova T. V., Ignatov M. S. \& Konstantinova N. A. 2010. To bryoflora of lowlands of Republic of Adygeya (Belaya River Basin). In: T. A. OvsYANNIKova (ed.), Proceedings of XVI International Conference "Ekologicheskie problemy sovremennosti. Ratsional'noe prirodopol'sovanie i sochranenie biorasnoobrasiya”, 3: 120-128. Izdatelstvo Maikop (in Russian).

Akatova T. V. \& OTTE V. 2007. Bryophytes of the Nature Park "Bol'šoj Thač" and adjacent territories. Abh. Ber. Naturkundemus. Görlitz 79(1): 115-130.

BAKALIN V. A. 2005. Monograficheskaya obrabotka roda Lophozia (Dum.) Dum. Nauka, Moscow.

BAKALIN V. A. 2010. The distribution of bryophytes in the Russian Far East. Part 1. Hepatics. Publishing Company of the Far Eastern University, Vladivostok (in Russian with English summary).

Bombosch A., Wieneke A., Busch A., Jonas R., HentSCHEl J., Kreier H.-P., Show B., Shaw A. J. \& HeinRICHS J. 2010. Narrow species concept in the Frullania dilatata-appalachiana-eboracensis complex (Porrelales, Jungermanniopsida): evidence from nuclear and chloroplast DNA markers. Pl. Syst. Evol. 290: 151-158.

BRotheruS V. F. 1892. Enumeratio muscorum Caucasi. Hepaticae. Acta Soc. Sci. Fenn. 19(12): 141-161.

Choi S. S., BaKalin V. A. \& Sun B.-Y. 2012. Scapania and Macrodiplophyllum in the Russian Far East. Botanica Pacifica 1(1): 31-95.

DudA J. 1982. On distribution of hepatics in Caucasus. Novosti Sist. Nizsh. Rast. 19: 200-204 (in Russian).
GRADSTEIN S. R. \& VÁŇA J. 1987. On the occurrence of Laurasian liverworts in the tropics. Mem. New York Bot. Gard. 45: $388-425$.

Grossheim A. A. 1936. Analysis of the flora of the Caucasus. Trudy Aserbajdzansk. Otd. Zakavkazksk. Fil. Akad. Nauk SSSR 1: 1-257 (in Russian with English summary).

HATTORI S. 1978. Notes of the Asiatic species of the genus Frullania, Hepaticae, XI. J. Hattori Bot. Lab. 44: 525-554.

Konstantinova N. A. 2008. Hepatics. In: E. A. Ignatova, M. S. Ignatov, N. A. Konstantinova, V. I. Zolotov \& V. G. ONIPCHENKO 2008. Flora mokhoobrasnykh Teberdinskogo Zapovednika. Flora i Fauna Zapovednikov 112: 7-27 (In Russian).

Konstantinova N. A. 2011. Contribution to the hepatic flora of the Republic of Dagestan (Eastern Caucasus, Russia). Arctoa 20: 175-182.

Konstantinova N. A., Akatova T. V. \& SavchenKo A. N. 2009c. Hepatics of Caucasian State Nature Reserve (Northwest Caucasus, Russia). Arctoa 18: 121-134.

Konstantinova N. A. \& BaKalin V. A., Andrejeva E. N., Bezgodov A. G., Borovichev E. A., Dulin M. V. \& MAMONTOV Y. S. 2009b. Checklist of liverworts (Marchantiophyta) of Russia. Arctoa 18: 1-64.

Konstantinova N. A., Ignatov M. S., Ignatova E. A. \& KHARSINOV Z. KH. 2009a. New liverwort records from Republic of Kabardino-Balkariya. 1. Arctoa 18: 263-267.

Konstantinova N. A. \& Savchenko A. N. 2011. To the liverwort flora of the Sochi National Park (Western Caucasus, Russia). Novosti Sist. Nizsh. Rast. 45: 301-317 (in Russian with English summary).

Konstantinova N. A. \& Savchenko A. N. 2012. Hepatics in surroundings of the town of Lazarevskoe (Western Caucasus, Russia). Chornomorskiy. Bot. Zhurn. (Moscow \& Leningrad) 8(1): 56-66.

Konstantinova N. A. \& VILNET A. A. 2011. Jubula hutchinsiae (Hook.) Dumort. subsp. caucasica subsp. nov. (Jubulaceae, Marchantiophyta) - new taxon from Western Caucasus. Arctoa 20: 227-238.

Mamontov Yu. S., Konstantinova N. A. \& Afonina O. M. 2010. New liverwort records from Zabaikal'sky Territory. 4. Arctoa 19: 275-277.

Mamontov Yu. S., Konstantinova N. A. \& Afonina O. M. 2011. New liverwort records from Zabaikal'sky Territory. 5. Arctoa 20: 259-261.

Mamontov Yu. S. \& Afonina O. M. 2012. New liverwort records from Zabaikal'sky Territory. 6. Arctoa 21: 290-294.

Oтte V. 2001. Flechten und Moose im Gebiet des Bolschoi Tchatsch (NW-Kaukasus) - eine erste Ubersicht, erganzt durch einige von D. Benkert bestimmte Peziziales. Feddes Repert. 112(7-8): 565-582. 
OTTE V. 2006. Erster Nachweis von Frullania bolanderi (Marchantiophyta: Jubulaceae) im Kaukasus. Herzogia 19: 353-355.

PAVLOV N. V. 1948. Vegetation of mesophyllous centers of the Caucasus and Talysh. In: N. V. PAVLOV, Botanicheskaya geografiya SSSR, pp. 316-335. Izdatel'stvo Akademii Nauk Kasakhskoy SSR, Alma-Ata (in Russian).

Perold S. M. 1999. Flora of South Africa which deals with the territories of South Africa, Lesotho, Swaziland, Namibia and Botswana. Hepatophyta. Part 1: Marchantiidaea. National Botanical Institutes, Pretoria.

PIIPPO S. 1990. Annotated catalogue of Chinese Hepaticae and Anthocerotae. J. Hattori Bot. Lab. 68: 1-192.

Potemkin A. D. \& Doroshina G. YA. 2009. To the liverwort flora of the Russian part of Caucasus. Novosti Sist. Nizsh. Rast. 43: 377-391 (in Russian with English summary).

Potemkin A. D. \& Urbanavichus G. P. 2010. New liverwort records from Republic of Dagestan. Arctoa 19: 273-274 (in Russian).

Potemkin A. D., Doroshina G. YA. \& Urbanavichus G. P. 2010. To the study of liverworts of Dagestan. Bot. Zhurn. 95(11): 1625-1638 (in Russian with English summary).

Rubasinghe S. C. K. 2011. Phylogeny and taxonomy of the complex thalloid liverwort family Cleveaceae Cavers. $\mathrm{PhD}$ Thesis, University of Edinburgh, Edinburgh

Rubasinghe S. C. K., Long D. G. \& Milne R. 2011. A new combination and three new synonyms in the genus Clevea Lindb. (Marchantiopsida, Cleveaceae). J. Bryol. 33(2): 168-169.

SCHUMACKER R. \& MATRINY PH. 1995. Threatened bryophytes in Europe including Macaronesia. In: E.C.C.B. (ed.), Red Data Book of European bryophytes. 2: 29-193. ECCB, Trondheim.

SCHUMACKER R. \& VÁŇA J. 2005. Identification keys to the liverworts and hornworts of Europe and Macaronesia (distribution and status). $2^{\text {nd }}$ edition fully revised and updated. Sorus, Poznań.
SCHUSTER R. M. 1974. The Hepaticae and Anthocerotae of North America east of the hundredth meridian. 3. Columbia University Press, New York and London.

SCHUSTER R. M. 1992. The Hepaticae and Anthocerotae of North America east of the hundredth meridian. 5. Field Museum of Natural History, Chicago.

ŞTEFĂNUȚ S. 2008. The Hornwort and Liverwort Atlas of Romania. Ars Docendi, Universitatea din Bucureşti, Bucureşti.

Stephani F. 1910. Species Hepaticarum 4. Geneve et Bale, Lyon.

SÖDERSTRÖM L, URMI E. \& VÁŇA J. 2002. Distribution of Hepaticae and Anthocerotae in Europe and Macaronesia. Lindbergia 27: 3-47.

SÖDERSTRÖM L., URMI E. \& VÁŇA J. 2007. Distribution of Hepaticae and Anthocerotae in Europe and Macaronesia Update 1-427. Cryptogam. Bryol. 28(4): 299-350.

TAKHTAJAN A. 1978. The floristic regions of the world. Nauka, Leningrad (in Russian).

VÁŇA J. 1973. Studien über die Jungermannioideae (Hepaticae). 3. Jungermannia subg. Liochlaena. Folia Geobot. Phytotax. 8(4): 397-416.

VÁŇA J. 1974. Studien über die Jungermannioideae (Hepaticae). 6. Jungermannia subg. Solenostoma: europäische und nordamerikanische Arten. Folia Geobot. Phytotax. 9: 369-423.

VÁŇA J. 1982. A contribution to the study of the hepatics (Hepaticae) of the Teberdinsky Zapovednik (Caucasus, USSR). Novit. Bot. Univ. Carol. 1: 15-21.

VÁŇA J. \& IGNATOV M. S. 1995. Bryophytes of Altai Mountains. Preliminary list of Altaian hepatics. Arctoa 5: 1-14.

Vilnet A. A., Konstantinova N. A. \& TROITSKy A. V. 2008. Phylogeny and systematics of the genus Lophozia s. str. (Dumort.) Dumort. (Hepaticae) and related taxa from nuclear ITS1-2 and chloroplast trnL-F sequences. Molec. Phylogenet. Evol. 47: 403-418. 